\title{
Absence of prostaglandins in semen of men with cystic fibrosis is an indication of the contribution of the seminal vesicles
}

\author{
E. Bendvold*, C. Gottlieb*, K. Svanborg*, H. Gilljam†, B. Strandvik $\$$, \\ M. Bygdeman* and P. Eneroth* \\ *Department of Obstetrics and Gynecology, Karolinska Hospital, S-10401 Stockholm, Sweden; \\ $\ddagger$ Department of Pediatrics, and $\dagger$ Department of Lung Medicine, Huddinge Hospital, S-141 86 \\ Huddinge, Sweden
}

\begin{abstract}
Summary. Five men with cystic fibrosis delivered semen samples which were analysed for the content of the four main groups of prostaglandins (PGs). No PGs could be found in any of the specimens. The results of the present study provide further evidence that the seminal vesicles constitute the dominant site of production of PGs in human semen.
\end{abstract}

\section{Introduction}

For more than 2 decades the seminal vesicles have been assumed to be the main site of production of the prostaglandins (PGs) in human semen, but definite proof is still lacking. The studies by Eliasson (1959), Brummer (1973) and Hamberg (1976) indicate that the PGs in semen originate in the seminal vesicles. We have recently presented data which support the assumption that the seminal vesicles are the main source of seminal PGs (Bendvold, Svanborg, Bygdeman \& Norèn, 1985). Our further investigations of the origin of PGs in human seminal fluid concerned the genital abnormalities found in male patients with cystic fibrosis.

Since publication of the reports by Denning, Sommers \& Quigley (1968) and Kaplan et al. (1968) it has been considered that severe cystic fibrosis is associated with infertility due to azoospermia. The azoospermia is probably due to malformations in the genital tract, including absence of seminal vesicles. In a series of 29 consecutive autopsies of cystic fibrosis patients, Holsclaw, Perlmutter, Jockin \& Shwachman (1971) could not find any seminal vesicles. The present study therefore was designed to analyse PGs in semen from patients with cystic fibrosis who were believed to lack seminal vesicles.

\section{Materials and Methods}

Five males participated in the study. They were between 19 and 65 years old and had had typical symptoms since childhood and pathological sweat test $(>80 \mathrm{mmol}$ chloride $/ \mathrm{l})$. None of the men had ever made a woman pregnant. Because of their disease they were regularly treated with mucolytica and fat-soluble vitamins. All except one had pancreatic enzyme supplementation. Two were on antibiotics at the time of investigation. None of them had taken prostaglandin biosynthesis inhibitors during at least the 2 weeks preceding the investigation. The subjects underwent a thorough genital examination.

One semen sample was obtained from each man by masturbation at the laboratory. The specimen was gently shaken for $30 \mathrm{~min}$ at room temperature and then a small part of the sample was withdrawn 
for a sperm count and an examination of the fructose and acid phosphatase levels. From two samples, an additional aliquant was removed for measurement of the lactoferrin level. The major part of the semen samples was used for analysis of the concentration of the PGs. The concentration of 15-keto-13,14-dihydro PGF-2 $\alpha$ was measured in plasma by RIA.

Two physically healthy men who were both azoospermic for other reasons delivered one semen sample each. The samples were analysed for the PG content.

The content of fructose was determined by the enzymic assay described by Bernt $\&$ Bergmeyer (1974). The acid phosphatase was analysed by the method of Lizana, Moberg \& Eneroth (1983). Lactoferrin was quantified by electroimmunoassay (Eneroth, Lizana \& Bygdeman, 1984).

The semen fraction used for the analysis of PGs was mixed with 10 times as much of acetone and stored at $-20^{\circ} \mathrm{C}$ until the analysis was performed. In brief, the method, which is described in detail elsewhere (Svanborg, Bygdeman, Eneroth \& Bendvold, 1982), consists of alkali treatment whereby the PGEs and 19-hydroxy-PGEs are converted to the respective PGB compounds. Following purification and separation by different chromatography steps, the PGBs and 19-hydroxyPGBs are normally quantified by their u.v.-absorbance and the PGFs and the 19-hydroxy-PGFs by gas chromatography. In the present study, the occurrence of interfering substances, mainly fatty acids, greatly influenced the measurement of PGBs by u.v.-absorption. Therefore, the method was slightly modified so that all the four main groups of PGs were quantified by gas chromatography. This modification of the method has also been described in detail (Svanborg et al., 1982).

\section{Results}

All the patients had a normal male habitus. The external genitalia were found on physical examination to be normal. On palpation the testes seemed normal in size and consistency. In all patients the epididymides were either absent or reduced in size. The vas deferens could either not be palpated or was thick and fibrous. The prostate was normal in all cases. No seminal vesicles could be palpated. The concentration of the PGF metabolite in plasma was between 0.26 and $0.35 \mathrm{nmol} / 1$.

The freshly collected semen samples were homogeneous and of a normal greyish colour when received. None of the specimens showed evidence of coagulation. All the samples were small in volume, $0.8 \pm 0.5 \mathrm{ml}$ (mean \pm s.d.). A detailed analysis of multiple high-power fields by microscopy revealed no spermatozoa in any specimen.

The semen samples contained small amounts of fructose, $2 \cdot 8 \pm 2 \cdot 2 \mathrm{mmol} / \mathrm{l}$, and increased levels of acid phosphatase, $25.9 \pm 12.3 \mathrm{mkatal} / 1$ (mean \pm s.d.). The concentration of lactoferrin was analysed in aliquants from two semen samples. Very low concentrations, $<40 \mathrm{mg} / \mathrm{l}$, were found. No amounts of any of the four main groups of PGs were found (limit of detection $0.3 \mathrm{mg} / \mathrm{l}$ ).

In semen samples from two men with azoospermia not due to cystic fibrosis the concentrations of PGE and 19-hydroxy-PGE were 137 and $312 \mathrm{mg} / \mathrm{l}$ in one semen sample and 34 and $137 \mathrm{mg} / \mathrm{l} \mathrm{in}$ the other.

\section{Discussion}

Azoospermia in males with cystic fibrosis has been almost universally observed (Denning et al., 1968; Holsclaw et al., 1971; Rule, Kopito \& Schwachman, 1970). Our finding of azoospermia in all the semen samples further supports this observation. That azoospermia per se does not mean that PGs are absent is illustrated by our finding of normal levels of PGs in the semen from azoospermic but otherwise normal men.

There are several reasons for believing that the 5 men with cystic fibrosis in the present study lacked seminal vesicles. The prostate gland, but not the seminal vesicles, could be palpated and the 
volumes of the ejaculates were small. The protein lactoferrin is considered to be produced mainly by the seminal vesicles (Tauber, Zaneveld, Propping \& Schumacher, 1975). The levels of lactoferrin found in the present study were much lower than the average concentration occurring in seminal fluid from normal men $(533 \pm 304 \mathrm{mg} / \mathrm{l})$ (Eneroth et al., 1984). Fructose is also generally considered to be mainly of seminal vesicle origin (Mann, 1964). The small amounts of fructose found in the semen samples of the cystic fibrosis patients in the present study may very well be of prostatic origin. Fair, Crane, Schiller \& Heston (1979) and Zaneveld \& Tauber (1981) have reported small amounts of fructose in expressed prostatic secretions and in the first fraction of split ejaculates, respectively. Elevated amounts of acid phosphatase were also observed in all the semen samples.

Normally, semen samples coagulate immediately after ejaculation and do not liquefy until 20$30 \mathrm{~min}$ later. In the present study the formation of a visible coagulum did not occur in any specimen. The first step in the normal coagulation-liquefaction sequence is the formation of a clot catalysed by the action of a clotting enzyme on a coagulable protein. This protein is secreted in the seminal vesicles (Mann \& Lutwak-Mann, 1981). The lack of coagulation, together with the data on the concentration of fructose, acid phosphatase and lactoferrin in the ejaculate, are in accordance with the proposition that there is no contribution from the seminal vesicles and that most of the ejaculate comes from the prostate (Rule et al., 1970).

Attention has been given to the possibility of an altered metabolism of PGs because essential fatty acids are not metabolized in the normal manner in cystic fibrosis patients (Anderson, 1984; Goodchild, Laing, Custance, Vaughan \& Dodge, 1984). However, there is no evidence that cystic fibrosis patients in general are unable to synthesize PGs (Lemen et al., 1978). It also seems unlikely that a general ability to synthesize PGs is associated with a defect in the production of these compounds in the genital tract. The plasma levels (mean \pm s.d.) of the PGF metabolite, 0.26 to $0.35 \mathrm{nmol} / \mathrm{l}$, were similar to those in healthy men, $0.25 \pm 0.07 \mathrm{nmol} / 1$ (unpublished observation).

The ejaculates from the 5 men in the present study may therefore be considered to consist of secretions from the prostate and the urethral glands. We could not detect any PGs in the semen samples analysed. Therefore, although it has been reported that tissue from the prostate gland can produce PGs from arachidonic acid in vitro (Conte et al., 1980), it is unlikely that this ability contributes significantly to the presence of PGs in semen in vivo. In a previous study we reported that the contribution of PGs from the testis, the epididymis and the vas deferens is insignificant (Bendvold et al., 1985). The present study therefore provides further support for the proposition that the seminal vesicles are the main site of production of PGs in human semen.

This study was supported by the Swedish Medical Research Council (B85-17X-05696-06A). We thank Professor Hans Kindahl for the RIA analyses of the PGF metabolite; Astrid Häggblad who prepared the manuscript; and Dr Zoe Walsh who corrected the English.

\section{References}

Anderson, C.M. (1984) Hypothesis revisited: cystic fibrosis: a disturbance of water and electrolyte movement in exocrine secretory tissue associated with altered prostaglandin $\left(\mathrm{PGE}_{2}\right)$ metabolism? J. Pediatr. Gastroenterol. Nutr. 3, 15-22.

Bendvold, E., Svanborg, K., Bygdeman, M. \& Norén, S. (1985) On the origin of prostaglandins in human seminal fluid. Int. J. Androl. 8, 37-43.

Bernt, E. \& Bergmeyer, H.U. (1974) D-Fructose. In Methods of Enzymatic Analysis, vol. 3, pp. 1304-1307. Ed. H. U. Bergmeyer. Academic Press, New York.

Brummer, H.C. (1973) Vasectomy and seminal prostaglandins. Fert. Steril. 24, 131-133.
Conte, D., Laguzzi, G., Boniforti, L., Cantafora, A., Disilverio, F., Latino, C., Lalloni, G., Mesollella, V. \& Isidori, A. (1980) Prostaglandin content and metabolic activity of the human prostate. In Prostaglandins and Reproductive Physiology, pp. 89-96. Eds A. Crastes de Paulet, H. Thaler-Dao \& F. Dray. Inserm, Paris.

Denning, C.R., Sommers, S.C. \& Quigley, H.J. (1968) Infertility in male patients with cystic fibrosis. Pediatrics 41, 7-17.

Eliasson, R. (1959) Studies on prostaglandins. Occurrence, formation and biological actions. Acta physiol. scand., Suppl. 158, 1-73. 
Eneroth, P., Lizana, J. \& Bygdeman, M. (1984) Lactoferrin and transferrin levels in the seminal plasma of infertile men. In Protides of the Biological Fluids, vol 31, pp. 149-153. Ed. H. Peeters, Pergamon, Oxford.

Fair, W.R., Crane, D.B., Schiller, N. \& Heston, W.D.W. (1979) A re-appraisal of treatment in chronic bacterial prostatitis. J. Urol. 121, 437-441.

Goodchild, M.C., Laing, S., Custance, J., Vaughan, M. \& Dodge, J.A. (1984) Essential fatty acid supplementation: absorption and metabolism. In Cystic Fibrosis: Horizons, pp. 409-420. Ed. D. Lawson. John Wiley \& Sons, Chichester.

Hamberg, M. (1976) Biosynthesis of prostaglandins $E_{1}$ by human seminal vesicles. Lipids 11, 249-250.

Holsclaw, D.S., Perlmutter, A.D., Jockin, H. \& Shwachman, H. (1971) Genital abnormalities in male patients with cystic fibrosis. J. Urol. 106, 568-574.

Kaplan, E., Shwachman, H., Perlmutter, A.D., Rule, A., Khaw, K.T. \& Holsclaw, D.S. (1968) Reproductive failure in males with cystic fibrosis. N. Engl. J. Med. 279, 65-69.

Lemen, R.J., Gates, A.J., Mathé, A.A., Waring, W.W., Hyman, A.L. \& Kadowitz, P.D. (1978) Relationships among digital clubbing, disease severity, and serum prostaglandin $\mathrm{F}_{2}$ alpha and $\mathrm{E}$ concentrations in cystic fibrosis patients. Am. Rev. Respir. Dis. 117, 639-646.
Lizana, J., Moberg, P. \& Eneroth, P. (1983) Beta ${ }_{2}$-microglobulin, carcinoembryonic antigen and prostatic acid phosphatase in split ejaculates and urine voided before and after massage of the prostate. Arch. Androl. 11, 225-232.

Mann, T.R. (1964) The Biochemistry of Semen and of the Male Reproductive Tract. John Wiley \& Sons, Inc., New York.

Mann, T.R.\& Lutwak-Mann, C. (1981) Male Reproductive Function and Semen. Springer Verlag, Berlin.

Rule, A.H., Kopito, L. \& Shwachman, H. (1970) Chemical analysis of ejaculates from patients with cystic fibrosis. Fert. Steril. 21, 515-520.

Svanborg, K., Bygdeman, M., Eneroth, P. \& Bendvold, E. (1982) Quantification of prostaglandins in human seminal fluid. Prostaglandins 24, 363-375.

Tauber, P.F., Zaneveld, L.J.D., Propping, D. \& Schumacher, G.F.E. (1975) Components of human split ejaculates. I. Spermatozoa, fructose, immunoglobulins, albumin, lactoferrin, transferrin, and other plasma proteins. J. Reprod. Fert. 43, 249-267.

Zaneveld, L.F.D. \& Tauber, P.F. (1981) Contribution of prostatic fluid components to the ejaculates. Progress in Clinical and Biological Research, 75A, 265-277.

Received 4 April 1986 